\title{
Penggunaan Fitur Saliency-SURF Untuk Klasifikasi Citra Sel Darah Putih Dengan Metode SVM
}

\author{
Siska Devella*1, Yohannes $^{2}$, Celvine Adi Putra ${ }^{3}$ \\ ${ }^{1,2,3}$ Program Studi Informatika, Fakultas Ilmu Komputer dan Rekayasa, \\ Universitas Multi Data Palembang; Jl. Rajawali No. 14 Palembang \\ e-mail: *1 siskadevella@mdp.ac.id, ${ }^{2}$ yohannesmasterous@mdp.ac.id, \\ ${ }^{3}$ celvineadiputra@gmail.com
}

\begin{abstract}
Abstrak
Sel darah putih merupakan sel pembentuk komponen darah yang berfungsi melawan berbagai penyakit dari dalam tubuh (sistem kekebalan tubuh). Sel darah putih dibagi menjadi lima jenis, yaitu basofil, eosinofil, neutrofil, limfosit, dan monosit. Pendeteksian jenis sel darah putih dilakukan di laboratorium yang memerlukan seorang spesialis serta usaha yang lebih, waktu, dan biaya. Solusi yang dapat dilakukan salah satunya adalah menggunakan machine learning seperti support vector machine (SVM) dengan ekstraksi fitur SURF. Penelitian ini menggunakan dataset citra sel darah putih yang sebelumnya dilakukan tahap pre-processing yang, terdiri dari crop, resize, dan saliency. Metode saliency mampu memberikan bagian yang bermakna pada sebuah citra. Metode ekstraksi fitur SURF mampu memberikan keypoint yang dapat digunakan SVM dalam mengenali jenis sel darah putih. Penggunaan region-contrast saliency dengan kernel radial basis function (RBF) mendapatkan hasil akurasi, presisi, dan recall yang baik di bandingkan dengan penggunaan kernel lain dalam penelitian ini. Berdasarkan hasil pengujian yang didapat pada penelitian ini, saliency dapat meningkatkan hasil akurasi, presisi, dan recall dari SVM untuk dataset citra sel darah putih dibandingkan dengan tanpa saliency.
\end{abstract}

Kata kunci-Sel Darah Putih; Saliency; SURF; SVM

\begin{abstract}
White blood cells are cells those formers blood components that function to fight various diseases from the body (immune system). White blood cells can be further into five types: basophils, eosinophils, neutrophils, lymphocytes, and monocytes. Detection of this type of white blood cell is able in a laboratory, which requires a specialist and extra effort, time, and money. One solution can use machine learning like a support vector machine (SVM) with SURF feature extraction. This study used a dataset of white blood cell images that previously carried out a pre-processing stage consisting of the crop, resize, and saliency. The saliency method can provide a meaningful part of an image. The SURF feature extraction method can provide a keypoint that SVM can use in recognizing white blood cell types. The use of region contrast saliency with kernel radial basis function $(R B F)$ results in good accuracy, precision, and recall compared to other kernels in this study. Based on the test results obtained in this study, saliency can improve the accuracy, precision, and recall results of the SVM for the white blood cell image dataset compared to those without saliency.
\end{abstract}

Keywords - White blood cells; Saliency; SURF; SVM 


\section{PENDAHULUAN}

Sel darah putih merupakan bagian dari tubuh manusia yang sangat penting dan bertugas untuk melindungi tubuh dari penyakit yang disebabkan oleh bakteri, parasit, dan virus [1]. Sel darah putih merupakan salah satu dari sistem kekebalan tubuh manusia berupa jaringan kompleks yang terdiri dari sel, jaringan, dan organ yang bekerja bersama untuk menjalankan fungsinya. Leukosit atau sel darah putih yang diproduksi oleh jaringan hemopoetik untuk jenis bergranula (polimorfonuklear) dan jaringan limfatik untuk jenis tak bergranula (mononuklear), yang berfungsi dalam sistem pertahanan tubuh terhadap infeksi [1]. Sel darah putih mempunyai 5 sub-kelompok, 3 diantaranya memiliki granula di dalam sitoplasmanya yaitu basofil, eosinofil, dan neutrofil. Sedangkan 2 jenis lainnya tidak memiliki granula di dalam sitoplasmanya yaitu limfosit dan monosit. [2]

Klasifikasi sel darah biasanya dilakukan secara visual oleh seorang spesialis medis menggunakan mikroskop. Kegiatan ini memerlukan waktu yang lama dan lebih banyak energi sehingga dapat berpotensi memiliki hasil akurasi yang rendah, menggunakan mesin analisis sampel darah dapat dilakukan tetapi membutuhkan kalibrasi yang tepat dan dengan biaya yang mahal [3]. Klasifikasi jenis sel darah putih sendiri telah banyak dikembangkan dengan beberapa metode yang telah ada, pada penelitian sebelumnya klasifikasi jenis sel darah putih telah dilakukan dengan menggunakan metode Convolutional Neural Network (CNN), Support Vector Machine (SVM), Saliency, SIFT, SURF, HOG, dan metode lainnya.

Support Vector Machine (SVM) termasuk algoritma supervised untuk melakukan klasifikasi yang berkerja dengan cara mencari hyperplane dengan margin yang terbesar. SVM harus dilatih terlebih dahulu mana yang termasuk kelas A dan mana yang termasuk kelas B. Awalnya Support Vector Machine (SVM) digunakan untuk klasifikasi data ke dalam dua kelas. Pada perkembangannya, Support Vector Machine (SVM) dapat diperluas untuk klasifikasi multi kelas dengan sejumlah skema [4]. Binary Class SVM digunakan untuk menyelesaikan masalah klasifikasi untuk dua kelas, untuk model klasifikasi lebih dari dua kelas dapat menggunakan Multi Class SVM. Terdapat tiga hal yang harus ditentukan pertama kali, pertama support vectors, kedua hyperplane, dan yang terakhir margin terbesar. Penelitian yang menggunakan SVM untuk melakukan klasifikasi sel darah putih dilakukan oleh Bhima Caraka dkk [5] mendapatkan rata-rata akurasi sebesar $82,20 \%$. Selanjutnya penelitian yang dilakukan oleh William Fanz Lamberti [6] yang membandingkan SVM dengan menggunakan pendekatan CNN untuk klasifikasi sel darah putih dan sel darah merah mendapatkan bahwa pendekatan dengan SVM mampu mengungguli semua pendekatan lain yang digunakan pada penelitian ini.

Saliency merupakan algoritma yang mampu memberikan informasi penting pada bagian tertentu yang lebih dominan dibanding dengan bagian lainnya dalam sebuah citra. Saliency memiliki beberapa metode seperti region contrast, histogram contrast, local contrast, dan lainlain. Yohannes dkk [7] melakukan penelitian yang menggunakan saliency untuk mendeteksi malaria dengan CNN. Penelitian ini membandingkan beberapa metode saliency untuk mendeteksi penyakit malaria, dengan menggunakan metode frequency-tuned saliency mendapatkan akurasi sebesar 90,32\%; metode region contrast saliency mendapatkan akurasi sebesar 62,67\%; metode spectral residual saliency mendapatkan akurasi sebesar 50\%; dan metode histogram contrast saliency mendapatkan akurasi sebesar 79,06\%. Pada penelitian klasifikasi sel darah putih menggunakan Saliency-SIFT [8], region contrast saliency mendapatkan hasil terbaik dengan akurasi sebesar 77,08\%; presisi sebesar 52,36\%; dan recall sebesar 53,99\%. Penelitian lain tentang saliency yaitu klasifikasi jenis buah dam sayuran menggunakan SVM dengan fitur Saliency-HOG dan color moment, berhasil mendapatkan precision, recall, dan accuracy terbaik adalah 98,57\%; 98,55\%; dan 99,12\%. Kesimpulan dari penelitian ini menunjukkan bahwa Saliency-HOG sebagai fitur bentuk berbasis saliency mampu

Devella, et., al [Penggunaan Fitur Saliency-SURF untuk Klasifikasi Citra Sel Darah Putih Dengan Metode SVM] 
menjadi salah satu kombinasi yang memberikan gambaran bentuk berdasarkan wilayah yang lebih dominan pada citra [9].

Speed-Up Robust Features (SURF) pertama kali dipublikasi oleh peneliti dari ETH Zurich, Herbert Bay pada tahun 2006, SURF merupakan sebuah metode deteksi fitur yang menggunakan keypoint dari sebuah citra [10]. Pada penelitian klasifikasi motif Songket Palembang [11] menggunakan metode SURF sebagai ekstraksi fitur dan menghasilkan akurasi sebesar 79,26\%. Anas Mohd Noor dkk [12] melakukan penelitian mengenai klasifikasi sel darah putih dengan menggunakan SURF sebagai fitur dengan menggunakan dua metode klasifikasi yaitu SVM dan ANN dan menghasilkan akurasi di atas 90\%. Berdasarkan penelitian-penelitian terdahulu, penelitian ini bertujuan untuk melakukan klasifikasi citra sel darah putih dengan menggunakan Saliency sebagai pre-processing, metode SURF sebagai ekstraksi fitur dan SVM sebagai metode klasifikasi.

\section{METODE PENELITIAN}

Pada penelitian ini, menggunakan dataset Blood Cell Images yang berjumlah 12.500 citra sel darah putih yang didapatkan dari website kaggle, yang memiliki 4 jenis sel darah putih eosinophil, lymphocyte, monocyte, dan neutrophil, dapat dilihat pada Gambar 1. Tahapan metode dimulai dari dengan melakukan tahap pre-processing dengan tiga jenis saliency pada dataset. Selanjutnya dengan citra crop dan resize dengan ukuran 100×100 pixel, dilanjutkan dengan menyeleksi data untuk memisahkan data yang terdapat sel darah putih dan yang tidak mengandung sel darah putih, sehingga menghasilkan 2.000 citra per jenis sel darah putih, dan dilanjutkan dengan klasifikasi pada Support Vector Machine. Pada penelitian ini data dibagi menjadi dua bagian yaitu data training sebanyak $70 \%$ dan data testing sebanyak $30 \%$. Tahapan metode terdapat pada Gambar 2.

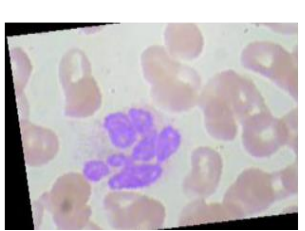

(a)

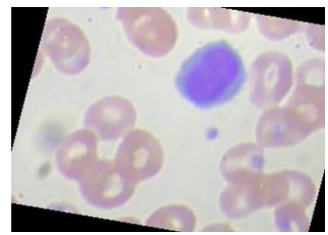

(b)

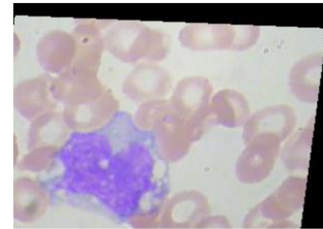

(c)

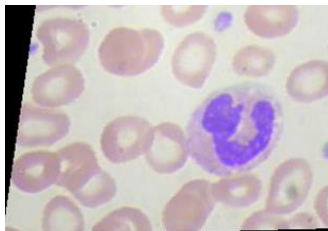

(d)

Gambar 1. (a) Eosinophil, (b) Lymphocyte, (c) Monocyte, dan (d) Neutrophil 


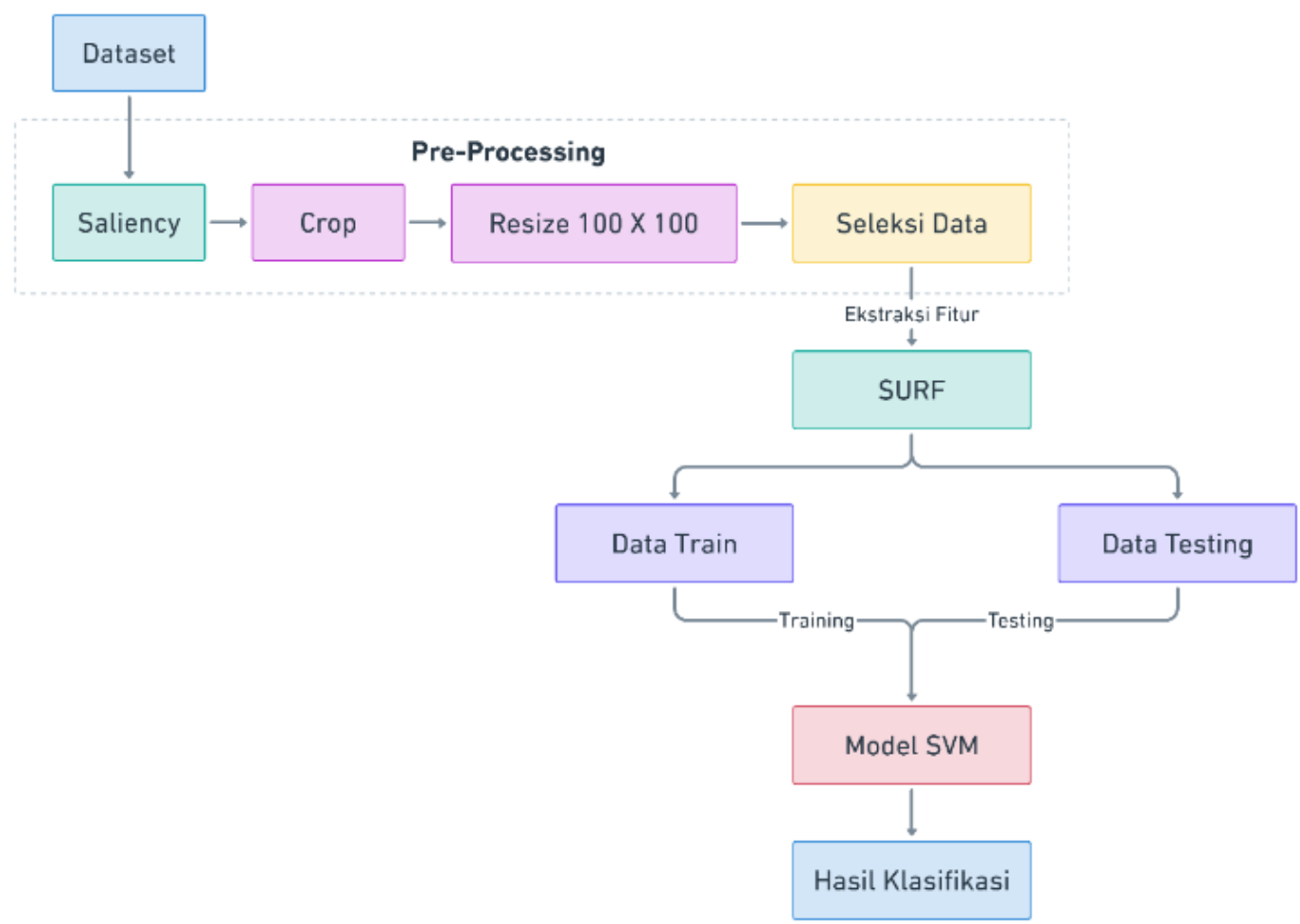

Gambar 2. Metode yang Digunakan

\subsection{Saliency}

Saliency adalah sebagai sebuah informasi pada bagian citra tertentu yang lebih diperhatikan, bermakna, dan berkesan dibandingkan dengan bagian-bagian lain di wilayah sekitarnya atau tetangganya. Saliency dibedakan menjadi dua macam yaitu bottom-up dan topdown. Bottom-up atau faktor kepekaan adalah melihat bagian tertentu dari suatu citra yang memiliki sifat yang lebih mencolok dari area sekitar sehingga menjadi menarik perhatian, sedangkan top-down atau faktor keinginan user adalah ketika sudah ditentukan terlebih dahulu bentuk, warna objek yang dicari berdasarkan keinginan, sehingga yang dikenali hanya objek yang memiliki bentuk dan warna yang sama. Pendekatan saliency yang paling banyak adalah menggunakan metode bottom-up [13]. Saliency terdapat beberapa metode, yaitu region contrast saliency, frequency saliency, spectral residual, dan histogram saliency. Saliency dapat sangat bermanfaat dalam klasifikasi citra karena dapat menghasilkan saliency map yang memberikan bagian yang bermakna dalam sebuah citra. Saliency map adalah hasil dari bagian yang merepresentasikan visual dari saliency ke dalam sebuah citra, yang didapatkan setelah dilakukan pengelompokan terhadap bagian-bagian yang dianggap penting dan membuang bagian yang dianggap tidak penting.

\subsection{Speed Up Robust Feature (SURF)}

SURF adalah sebuah metode yang digunakan untuk ekstraksi fitur lokal dari sebuah citra. Algoritma SURF menggabungkan algoritma citra integral dan blob detection berdasarkan determinan dari matrik. Algoritma SURF terdiri dari detector dan descriptor. Detector digunakan untuk menentukan keypoint dan descriptor digunakan untuk mengekstrak fitur dari setiap citra [10]. 


\subsection{Support Vector Machine}

Support Vector Machine di kembangkan pertama kali untuk klasifikasi biner atau klasifikasi dua kelas. Support vector machine mencoba untuk memisahkan dua buah kelas dengan mencari pemisah maksimal dengan jumlah data yang minimum. Support Vector Machine tidak dapat dikembangkan secara langsung untuk memecahkan masalah klasifikasi multi class. Pendekatan yang dapat digunakan untuk menyelesaikan masalah multi class, salah satu pendekatan yang dapat digunakan dengan menggunakan beberapa SVM biner untuk memisahkan setiap kelas. Sebagai contoh masalah tiga buah kelas untuk memisahkan kelas 1-2, 1-3, dan 2-3, metode ini disebut one-Against-One, dengan demikian melatih tiga SVM, dengan menggunakan metode ini sangat memakan waktu. Pendekatan lain yang dapat digunakan dengan menggunakan SVM biner untuk memisahkan setiap kelas dengan kelas lainnya, sebagai contoh masalah tiga kelas, maka untuk memisahkan kelas 1-(2,3), 2-(1,3), 3-(1,2), dengan menggunakan metode ini memiliki kelemahan terbentuknya area yang tidak dapat diklasifikasi atau bukan termasuk kelas manapun, metode ini disebut one-Against-All [14].

\subsection{Confusion Matrix}

Confusion matrix adalah sebuah metode yang digunakan atau memiliki fungsi untuk melakukan analisis apakah classifier tersebut baik dalam mengenali tuple dari kelas setiap yang berbeda. Nilai dari True Positive (TP) dan nilai True Negative (TN) memberikan informasi ketika classifier melakukan klasifikasi data yang bernilai benar, sedangkan False Positive (FP) dan True Negative (TN) memberikan informasi ketika classifier salah dalam melakukan klasifikasi data [15].

Tebel 1. Confusion Matrix Menampilkan
Total Positive dan Negative Tuple
\begin{tabular}{|c|c|c|c|}
\hline \multirow{4}{*}{ Aktual } & \multicolumn{3}{|c|}{ Prediksi } \\
\cline { 2 - 4 } & & YES & NO \\
\cline { 2 - 4 } & YES & TP & FN \\
\cline { 2 - 4 } & NO & FP & TN \\
\cline { 2 - 4 } & Total & P & N \\
\hline
\end{tabular}

Keterangan:

TP (True Positive) : Jumlah data dengan nilai sebenarnya positif dan nilai prediksi positif FP (False Negative) : Jumlah data dengan nilai sebenarnya negatif dan nilai prediksi positif FN (False Negative) : Jumlah data dengan nilai sebenarnya positif dan nilai prediksi negatif TN (True Negative) : Jumlah data dengan nilai sebenarnya negatif dan nilai prediksi negatif

Accuracy adalah rasio prediksi benar (positif dan negatif) dengan keseluruhan data. Accuracy dapat dihitung dengan Persamaan 1

Accuracy $=\frac{T P+T N}{T P+T N+F P+F N}$

Recall adalah rasio dari prediksi benar positif yang dibandingkan dengan keseluruhan data yang benar positif. Recall dapat dihitung dengan Persamaan 2

Recall $=\frac{T P}{T P+F N} \times 100 \%$

Precision adalah rasio dari prediksi benar positif yang dibandingkan dengan keseluruhan dari hasil yang prediksi positif. Precision dapat dihitung dengan Persamaan 3 
Precision $=\frac{T P}{T P+F P} \times 100 \%$

\section{HASIL DAN PEMBAHASAN}

\subsection{Hasil Penggunaan Saliency Pada Citra Sel Darah Putih}

Dari hasil penelitian yang dilakukan pada citra sel darah putih eosinophil, lymphocyte, monocyte, dan neutrophil maka didapat hasil dari saliency region contrast saliency, frequencytuned saliency, dan histogram contrast saliency pada citra sel darah putih. Hasil berupa citra tanpa saliency (Gambar 3) untuk setiap jenis sel darah putih dan hasil dari 3 jenis saliency, jenis region contrast saliency (Gambar 4) untuk setiap jenis sel darah putih, jenis histogram contrast saliency (Gambar 5) untuk setiap jenis sel darah putih, dan frequency-tuned saliency (Gambar 6) untuk setiap jenis sel darah putih. Masing-masing dari citra telah melalui tahap cropping dan resize dengan ukuran 100 x 100 pixel.

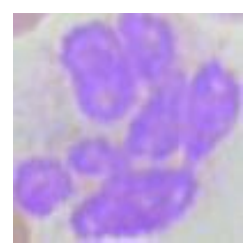

(a) Eosinophil

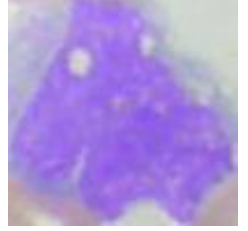

(c) Monocyte

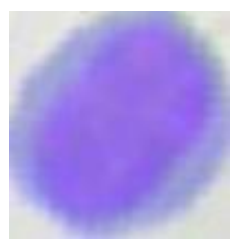

(b) Lymphocyte

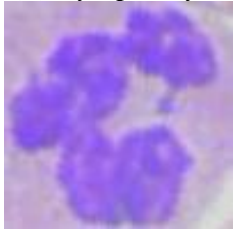

(d) Neutrophil

Gambar 3. Citra Asli Sel Darah Putih
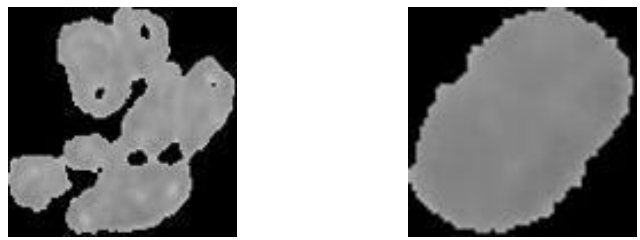

(a) Eosinophil
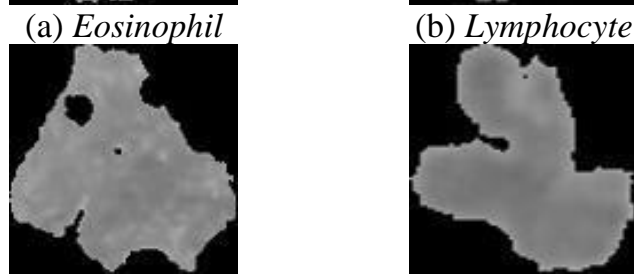

(c) Monocyte

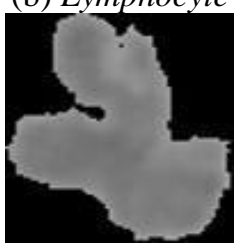

(d) Neutrophil

Gambar 4. Citra Region Contrast Saliency pada Citra Sel Parah Putih 


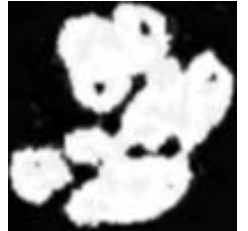

(a) Eosinophil

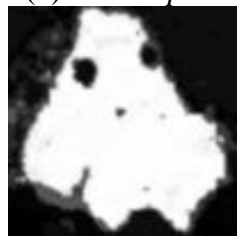

(c) Monocyte

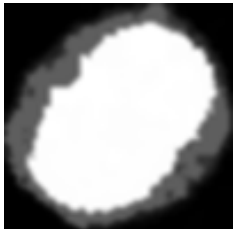

(b) Lymphocyte

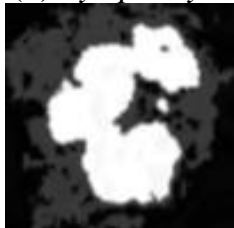

(d) Neutrophil

Gambar 5. Citra Histogram Contrast Saliency pada Citra Sel Darah Putih

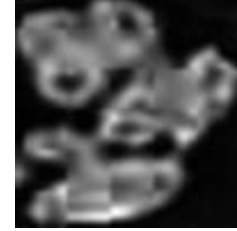

(a) Eosinophil

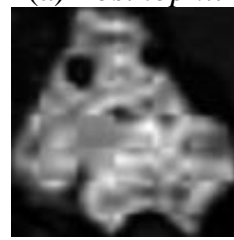

(c) Monocyte
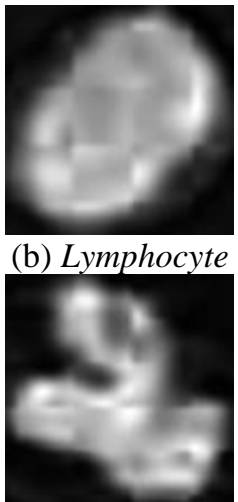

(d) Neutrophil

Gambar 6. Citra Frequency-Tuned Saliency pada Citra Sel Darah Putih

\subsection{Hasil Ekstraksi Fitur SURF dari Citra Saliency}

Hasil dari proses seleksi saliency selanjutnya dilakukan tahapan speed-up robust untuk mendapatkan bagian-bagian yang dianggap paling penting dari citra hasil saliency dan citra tanpa saliency, hasil visualisasi dari SURF berupa lingkaran dan titik. Lingkaran merupakan hasil dari perhitungan respons Haar Wavelet dengan arah $\mathrm{x}$ dan $\mathrm{y}$. Respons dihitung dalam lingkungan secara melingkar dengan radius 6s di sekitar keypoint. Sedangkan titik tengah merupakan visualisasi dari vector yang direpresentasikan sebagai kekuatan respons dalam arah horizontal, dan vertikal. Contoh citra tanpa saliency pada setiap jenis sel darah yang dilakukan tahap SURF dapat dilihat pada Gambar 7, nilai strongest yang digunakan pada SURF sebesar 16, dan lingkaran hijau dengan simbol plus menandakan keypoint yang digunakan dalam tahap klasifikasi dengan menggunakan SVM. Contoh citra saliency pada setiap jenis sel darah putih dengan menggunakan jenis region contrast saliency dapat dilihat pada Gambar 8. Selanjutnya contoh citra saliency untuk setiap jenis sel darah putih dengan menggunakan jenis histogram contrast saliency dapat dilihat pada Gambar 9. Contoh citra saliency untuk setiap jenis sel darah putih dengan menggunakan jenis frequency-tuned saliency dapat dilihat pada Gambar 10. 


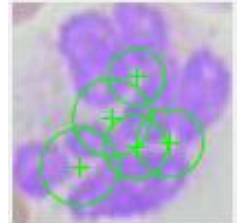

(a) Eosinophil

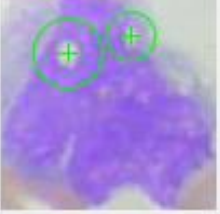

(c) Monocyte

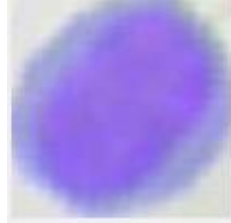

(b) Lymphocyte

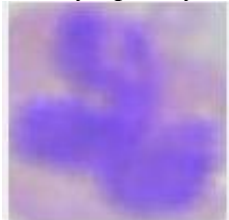

(d) Neutrophil

Gambar 7. Visualisasi Interest Point SURF pada Citra Asli Hasil SURF
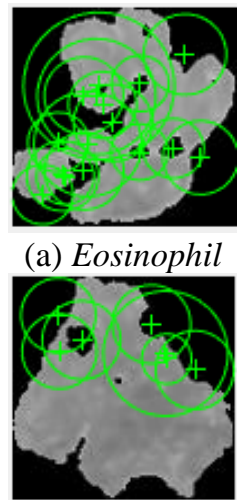

(c) Monocyte

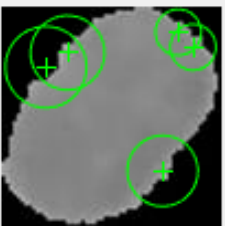

(b) Lymphocyte

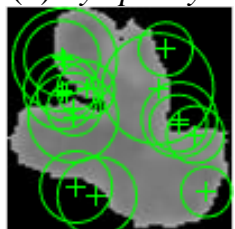

(d) Neutrophil

Gambar 8. Visualisasi Interest Point SURF pada Region Contrast Saliency

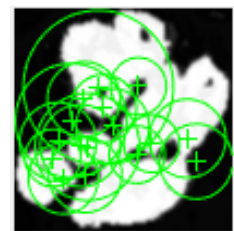

(a) Eosinophil

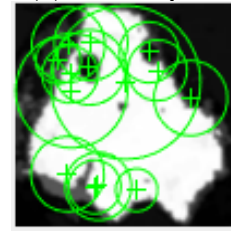

(c) Monocyte

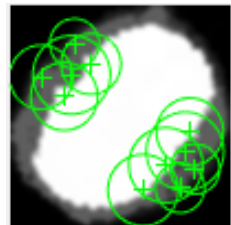

(b) Lymphocyte

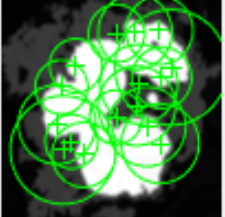

(d) Neutrophil

Gambar 9. Visualisasi Interest Point SURF pada Histogram Contrast Saliency 


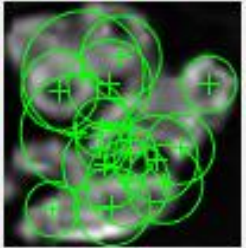

(a) Eosinophil

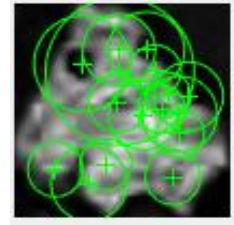

(c) Monocyte

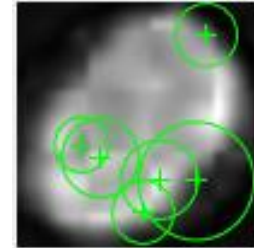

(b) Lymphocyte

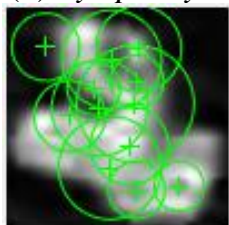

(d) Neutrophil

Gambar 10. Visualisasi Interest Point SURF pada Frequency-Tuned Saliency

\subsection{Tanpa Menggunakan Saliency}

Pengujian dengan menggunakan metode SVM dengan menggunakan kernel linear dengan nilai $\mathrm{C}$ sebesar 1.0, kernel radial basis function dengan nilai $\mathrm{C}$ sebesar 1.0 dan gamma scale, kernel polynomial dengan nilai degree sebesar 3 dan gamma scale, dan kernel sigmoid dengan nilai $\mathrm{C}$ sebesar 1.0 dan gamma scale. Hasilnya dapat dilihat pada Tabel 2.

Tabel 2. Perbandingan Hasil Kernel Tanpa Saliency

\begin{tabular}{|l|c|c|c|}
\hline \multicolumn{1}{|c|}{ Kernel } & Accuracy (\%) & Precision (\%) & Recall (\%) \\
\hline Linear & 74,64 & 44,29 & 49,06 \\
\hline Radial Basis Function & 76,06 & 49,28 & 51,92 \\
\hline Polynomial & 72,85 & 47,00 & 47,55 \\
\hline Sigmoid & 71,39 & 41,80 & 42,69 \\
\hline
\end{tabular}

\subsection{Menggunakan Region Contrast Saliency}

Pengujian dengan menggunakan metode SVM dengan menggunakan kernel linear dengan nilai $\mathrm{C}$ sebesar 1.0, kernel radial basis function dengan nilai $\mathrm{C}$ sebesar 1.0 dan gamma scale, kernel polynomial dengan nilai degree sebesar 3 dan gamma scale, dan kernel sigmoid dengan nilai $\mathrm{C}$ sebesar 1.0 dan gamma scale. Hasilnya dapat dilihat pada Tabel 3.

Tabel 3. Perbandingan Hasil Kernel Pada Region Contrast Saliency

\begin{tabular}{|l|c|c|c|}
\hline \multicolumn{1}{|c|}{ Kernel } & Accuracy $(\%)$ & Precision $(\%)$ & Recall $(\%)$ \\
\hline Linear & 77,87 & 53,09 & 55,56 \\
\hline Radial Basis Function & 78,60 & 55,22 & 57,03 \\
\hline Polynomial & 77,79 & 53,58 & 55,43 \\
\hline Sigmoid & 74,95 & 53,98 & 49,93 \\
\hline
\end{tabular}

\subsection{Menggunakan Histogram Contrast Saliency}

Pengujian dengan menggunakan metode SVM dengan menggunakan kernel linear dengan nilai $\mathrm{C}$ sebesar 1.0, kernel Radial basis function dengan nilai $\mathrm{C}$ sebesar 1.0 dan gamma scale, kernel polynomial dengan nilai degree sebesar 3 dan gamma scale, dan kernel sigmoid dengan nilai $\mathrm{C}$ sebesar 1.0 dan gamma scale. Hasilnya dapat dilihat pada Tabel 4. 
Tabel 4. Perbandingan Hasil Kernel pada Histogram Contrast Saliency

\begin{tabular}{|l|l|l|l|}
\hline \multicolumn{1}{|c|}{ Kernel } & Accuracy $(\%)$ & \multicolumn{1}{c|}{ Precision $(\%)$} & Recall (\%) \\
\hline Linear & 74,22 & 45,83 & 48,20 \\
\hline Radial Basis Function & 77,58 & 53,80 & 54,95 \\
\hline Polynomial & 76,37 & 50,61 & 52,53 \\
\hline Sigmoid & 71,16 & 46,05 & 42,31 \\
\hline
\end{tabular}

\subsection{Menggunakan Frequency-Tuned Saliency}

Pengujian dengan menggunakan metode SVM dengan menggunakan kernel linear dengan nilai $\mathrm{C}$ sebesar 1.0, kernel Radial basis function dengan nilai $\mathrm{C}$ sebesar 1.0 dan gamma scale, kernel polynomial dengan nilai degree sebesar 3 dan gamma scale, dan kernel sigmoid dengan nilai $\mathrm{C}$ sebesar 1.0 dan gamma scale. Hasilnya dapat dilihat pada Tabel 5.

Tabel 5. Perbandingan Hasil Kernel pada Frequency-Tuned Saliency

\begin{tabular}{|l|c|c|c|}
\hline \multicolumn{1}{|c|}{ Kernel } & Accuracy (\%) & Precision (\%) & Recall (\%) \\
\hline Linear & 70,62 & 37,54 & 41,08 \\
\hline Radial Basis Function & 71,16 & 39,44 & 42,16 \\
\hline Polynomial & 71,02 & 38,96 & 41,91 \\
\hline Sigmoid & 67,20 & 30,72 & 34,35 \\
\hline
\end{tabular}

\section{KESIMPULAN}

Berdasarkan hasil yang didapat dalam penelitian ini dapat ditarik kesimpulan menjadi beberapa kesimpulan antara lain sebagai berikut:

1. Akurasi yang baik didapat dengan menggunakan kombinasi region contrast saliency dan dengan menggunakan kernel Radial Basis Function. Hasil akurasi yang didapatkan dengan kombinasi ini sebesar 78,60\%; presisi sebesar 55,22\%; dan recall sebesar 57,03\%.

2. Jenis sel darah putih yang mudah dikenali adalah jenis sel darah putih limfosit dibandingkan dengan jenis sel darah putih lainnya untuk penggunaan dataset blood cell images.

3. Jenis Saliency, region contrast saliency, histogram contrast saliency, dan frequency-tuned saliency memberikan perubahan yang cukup besar untuk pengenalan jenis sel darah putih limfosit dan monosit, sedangkan untuk eosinofil, dan neutrofil perubahan yang terjadi tidak terlalu signifikan

4. Hasil pengujian untuk klasifikasi jenis sel darah putih dengan, urutan penggunaan jenis saliency yang menghasilkan akurasi yang tertinggi sampai yang terendah untuk penelitian ini adalah region contrast saliency, histogram contrast saliency, dan frequency-tuned saliency.

5. Hasil pengujian untuk klasifikasi jenis sel darah putih dengan, urutan penggunaan kernel SVM yang menghasilkan akurasi yang tertinggi sampai yang terendah untuk pada penelitian ini adalah Radial Basis Function, Linear, Polynomial, dan Sigmoid.

\section{SARAN}

Berdasarkan penelitian yang telah dilakukan terdapat beberapa saran dari penulis yang dapat dilakukan oleh peneliti selanjutnya diantara sebagai berikut:

1. Menggunakan algoritma klasifikasi yang lain untuk mencapai tingkat akurasi yang lebih maksimal.

2. Menambahkan jumlah data latih dan data uji atau menggunakan dataset lainnya kecuali White Blood Cell Images. 
3. Menggunakan metode preprocessing lain atau metode saliency lainnya

4. Menggunakan pendekatan yang berbeda untuk menentukan interest point yang lebih optimal selain menggunakan fitur SURF

\section{DAFTAR PUSTAKA}

[1] Merl James Macawile, Vonn Vincent Quiñones, Alejandro Ballado Jr., Jennifer Dela Cruz, and Meo Vincent Caya. 2018, "White Blood Cell Classification and Counting Using Convolutional Neural Network," International Conference on Control and Robotics Engineering, Vol. 3, pp. 259-263.

[2] Myrna LaFleur Brooks. 2005, Exploring Medical Language: A Student-Directed Approach, 7e ed. Mosby Elsevier.

[3] Filip Novoselnik, Ratko Grbić, Irena Galić, and Filip Dorić. 2018, "Automatic White Blood Cell Detection and Identification Using Convolutional Neural Network," International Conference on Smart Systems and Technologies (SST), pp. 163-167.

[4] Suyanto. 2018, Machine Learning: Tingkat Dasar dan Lanjut, Informatika, Bandung.

[5] B. Caraka, B. Alldino, A. Sumbodo, and I. Candradewi. 2017, "Klasifikasi Sel Darah Putih Menggunakan Metode Support Vector Machine (SVM) Berbasis Pengolahan Citra Digital," IJEIS, Vol. 7, No. 1, pp. 25-36.

[6] W. F. Lamberti. 2021, "Blood Cell Classification Using Interpretable Shape Features: A Comparative Study of SVM Models and CNN-Based Approaches," Computer Methods and Programs in Biomedicine Update, Vol. 1, p. 100023, doi: 10.1016/j.cmpbup.2021.100023.

[7] Y. Yohannes, Siska Devella, and Kelvin Arianto, 2020, "Deteksi Penyakit Malaria Menggunakan Convolutional Neural Network Berbasis Saliency," JUITA: Jurnal Informatika, Vol. 8, No. 1, pp. 37-44.

[8] Y. Yohannes, S. Devella, and W. Hadisaputra, 2021, "Pemanfaatan Scale Invariant Feature Transform Berbasis Saliency Untuk Klasifikasi Sel Darah Putih,” Jurnal Teknik Informatika dan Sistem Informasi, Vol. 7, No. 2, Aug. 2021, doi: 10.28932/jutisi.v7i2.3707.

[9] Y. Yohannes, Muhammad Rizky Pribadi, and Leo Chandra. 2020, "Klasifikasi Jenis Buah dan Sayuran Menggunakan SVM Dengan Fitur Saliency-HOG dan Color Moments, "ELKHA, Vol. 12, No. 2, pp. 125-131.

[10] H. Bay, T. Tuytelaars, and L. Van Gool. 2006, "SURF: Speeded Up Robust Features,"

[11] Y. Yohannes, S. Devella, and A. H. Pandrean, 2020, "Penerapan Speeded-Up Robust Feature pada Random Forest Untuk Klasifikasi Motif Songket Palembang," Jurnal Teknik Informatika dan Sistem Informasi, Vol. 5, No. 3, Jan. 2020, doi: 10.28932/jutisi.v5i3.1978. 
[12] Anas Mohd Noor, Zulkarnay Zakaria, Aishah Mohd Noor, and Ahmad Nasrul Norali, 2021, "Classification of White Blood Cells Based on SURF Feature,".

[13] Arif Khumaidi, 2015, “Deteksi Saliency pada Perangkat Bergerak,” Surabaya.

[14] Ameet V Joshi, 2020, Machine Learning and Artificial Intelligence, 1st ed. Springer.

[15] Jiawei Han, Jian Pei, and Micheline Kamber, Data Mining: Concepts and Techniques. Morgan Kaufmann, 2012. 